\title{
Developing (architectural) design knowledge: A learner-researcher study
}

\author{
Tanja GOLJA* and Lynette SCHAVERIEN \\ University of Technology, Sydney
}

\begin{abstract}
While design researchers use diverse approaches to study designing, nondesigners face specific impediments in adopting these research approaches in their quest to gain design knowledge. Recognizing such challenges, this paper outlines how one education academic engineered a first-person methodology to investigate the nature of designing. Through undertaking a learner-researcher study in an undergraduate architectural design basics subject, learning about design through learning to design, she tracked her developing design ideas and crystallized a view of architectural designing as a three-phase heuristic for value selection: imagining possibilities, interpreting ideas to form architectural principles and distilling quality. Her subsequent small-scale test of this value-selection design heuristic in recent cases of architectural design provided preliminary affirmation of its viability. This paper concludes by speculating on various research directions arising from this learnerresearcher methodology and a view of designing as value selection and, in particular, provoking consideration of how similar developmental data might be collected and analysed for explanatory insights in diverse design and educational contexts.
\end{abstract}

Keywords: Architectural design knowledge, first-person research methodology, learner-researcher, value selection, design heuristic.

\footnotetext{
" Corresponding author: Office of Deputy Vice-Chancellor (Teaching, Learning \& Equity) | University of Technology, Sydney | Australia | e-mail: tanja.golja@uts.edu.au 


\section{Approaches to gain knowledge about design}

As a non-designer and education academic, there is an opportunity for me (first author) to fill a gap in how design knowledge has been gathered to date. Before outlining how I might achieve this, I begin this paper by describing some of the ways in which data about designing has been collected previously. Analysing why these approaches were or were not available to me, I outline how a methodology was engineered to learn about the nature of designing. I acknowledge upfront that this work was undertaken as part of a doctoral investigation (Golja 2011) under the research mentorship of my doctoral supervisor (second author).

\section{Interview study}

When undertaking interview studies, researchers seek to elicit participants' recount of, reflection and opinion on their processes, observations, views and experiences. For example, Björklund (2013) and Cross and Clayburn Cross (1996) gathered data through interviewing professional designers to study design expertise. That was also Lawson's (1994) approach when he undertook in-depth interviews with eleven distinguished architects, arguing for the usefulness of knowing how a few outstanding architects work and think. However, Lawson had previously developed a design model (Lawson 1990) which became the basis for how he subsequently framed his interview questions. Using that interview data, he wrote detailed case studies and examined them against his particular views of designing. In contrast, unlike these researchers (Björklund 2013; Cross and Clayburn Cross 1996; Lawson 1994), design is a discipline outside my area of expertise and experience. I would therefore be confronted by the dilemma of which design meaning or approach to select from the various ideas that different designers would put forward. So, it would be very difficult, if not impossible, for me to attempt to identify designing in such interviews: I could not examine design as it actually occurred.

Addressing this problem of distance, Loukissas (2008) conducted a series of sixty indepth unstructured interviews in situ with design practitioners whilst at the same time gathering related data from "observations, simulations, journal articles, technical papers, books, images, and popular media" (p. 41). Collecting such material over a period of one year, he not only studied design artefacts but also tested personal conceptions of design in various ways. Though such data, together with the interviews, enabled Loukisass (2008) to gain snapshots of designing in operation, this approach would provide me with very limited opportunities to witness design development and, therefore, the actual process.

\section{Archival study}

In archival studies, researchers access documents and artefacts as traces of ideas, observations and experiences from the past, and they use that data to interpret events and evaluate particular ideas. Innovative buildings, for example, are often richly documented cases of designing with extensive material published in different media. For one case, 30 St Mary Axe in London, such archival data included a video documentary (von Arx and Müller 2006a), published accounts (Powell 2006), visual data (Foster 2007; Gregory 2003; Jenkins 2007; Powell 2006), models (Hwang et al. 2006; Powell 2006; Stacey 2004; von Arx and Müller 2006b), participant accounts (von Arx and Müller 2006b), interviews (von Arx and Müller 2006c) and monographs mapping historical developments in that firm's projects (Foster and Partners 2005; Jenkins 2002, 2004, 2007, 2009). On the other hand, Schön (1981, 1983, 1984, 1985, 
1987) used archival material drawn from design education to study designing. The chosen event was taken from the Architectural Education Study (AES) which undertook ethnographic observations of learning and teaching in various design studios over sixmonth periods (Porter and Kilbridge 1981a, 1981b). It was Roger Simmonds' (1981) AES fieldwork of a professional graduate degree course from which Schön selected data: a single audio-recorded design dialogue. He produced a long transcript of that design encounter between a teacher (Quist) and his student (Petra), subsequently analysing it for insights into designing. Though this approach was also open to me, I recognize that such archival material (including any primary sources) is already layered with interpretation and constrained in ways that might not be evident: specifically, in the varying and particular perspectives selected as data sources, the media or techniques used to collect that data, the extent to which such data represented the rich contextual influences at the study site and in the reporting of data. As a non-designer, it was also not possible for me to corroborate designing in such archival material unless I already had well-developed insights.

\section{Observational study}

When researchers carry out observational studies they collect data in situ and in real time, engaging with the everyday activities of the group they are studying, as Bucciarelli (1994) and Vinck (2003) did in their investigations of how engineering design occurred. Observing design practitioners in their natural settings is what Yaneva (2005, 2006,2009 ) also did in her ethnographic studies of Rem Koolhaas' Office for Metropolitan Architecture (OMA). Bemoaning that buildings were not investigated in the process of planning and designing, she wanted to shed light on "architecture in the making". There would be challenges, however, for me to gain such access to professional practice. Similar studies, though in other settings, have observed students learning to design: for example, as Simmonds (1981) did in his ethnographic study of a graduate studio class and as von Buttlar (1981) documented in his fieldwork observations and chronological account of day-to-day development in an eleven-week design studio. For me, that more familiar educational context would make it possible to gather data as designing took place and was supported by designers. However, it is not immediately apparent when designing actually occurs for these practitioners or students and there is difficulty in knowing how much designing is actually visible. Observations of the interactions and conversations between designers and with materials might be strongly bound to one particular context and time. As an observer, therefore, I might not be privy to various psychological processes knowable and accessible to the design practitioner or student. Furthermore, an observer's experience or lack of experience of designing could overlay or even distort this evidence in ways that might be difficult to detect.

\section{Participatory study}

In participatory studies, researchers become active participants in and the subjects of what they are studying, gaining first-hand experience and therefore access to developing insights. For example, Pedgley (2007) devised ways to collect data that elicited specific elements of his design activity amendable to verbal accounts. Researchers at the Spatial Information Architecture Laboratory also had such a research agenda in mind for their Australian Research Council funded project, Embedded Research Within Architectural Practice (SIAL, RMIT 2006). There, participating architect-researchers formed up distinctive investigations within different 
and unique practices to understand how innovation and development could be supported in contemporary architectural designing. One participating architectresearcher, for example, gathered data naturalistically "to capture the background, current conditions, development and environmental interactions of ... [her] role as an architectural designer in a firm whose practice is increasingly engaging with digital media" (Benton 2008, p. 50). Likewise, a participatory study, carefully chosen, could give me direct, real-time access to gathering data related to the processes of design and its development. At the same time, it would be possible for me to test the worth of any of my developing insights in the real-time context in which they arose. So, this participatory approach seemed promising as a way for me to gain knowledge about the nature of design.

To shed further light on particular strengths and weaknesses of such first-person studies, I consulted two related and well-established research traditions. Both selfexperimentation (Altman 1987; Martinelli, Czelusta and Peterson 2008a, 2008b) and autobiography (Clements 1999; Lancy 1993) provided evidence of the power of these methodologies and highlighted particular challenges that needed to be considered and addressed: for example, the complexity integral to a first-person naturalistic study, particularly with the unlimited access to the researcher-subject's observations, thoughts and ideas, the potentially large, comprehensive data set and the inherent noise operating in this real-life setting. Though I subsequently adopted a first-person research approach to gain design knowledge, I customized it in ways I now describe.

\section{Developing a first-person methodology to gain design knowledge}

My background in Education (formerly as a teacher and more recently as an academic supporting learning and teaching in a university) and my strong interest but lack of previous formal study in Architecture pre-disposed me towards undertaking a first-person study in architectural design. In essence, I set out to gain knowledge about the nature of design through learning to design, becoming a learner-researcher.

In taking account of my limited experiences of architectural designing and so as to hedge the chances that I might learn to design successfully, or at least gain useful insights into designing, what was needed was a context within higher education in which I could grow, first-hand and in real time, an understanding of design. All these considerations suggested participating as a mainstream student in a first year undergraduate architectural design subject. To locate a suitable subject, I consulted with colleagues at my university's School of Architecture. The objectives of Architectural Design: Design Basics, a core first year design subject, supported my focus on seeking to understand designing. I subsequently became a fully participating student in this design basics subject, learning alongside other students.

In a novel study such as this, it was crucial to identify, address and therefore diffuse the ethical risks involved, not only for me but also for the students and academics who would be participating in the subject and, therefore, in the research context. For example, in reporting this research, I recognized and acknowledged all references to students' and teaching staff's contributions to my learning to design, as is academic practice at my university (Assessment Procedures Manual UTS 2001/2010). Students and teachers could choose whether such acknowledgement was by real name or pseudonym, reflecting recent research practices that argue for participants' right to be identified and thereby safeguarding their ownership of work (Kelly 2009; Tilley and 
Woodthorpe 2011; Walford 2005). This study's context was also identified, to highlight its particularity and to avoid implying its generalizability by dislodging it from its particular history and geography (Nespor 2000; Walford 2005). Indeed, many scholarly architectural design communities accept and practise such protocols (for example, Hensel and Menges 2006, 2008a, 2008b; Sunguroglu 2008).

During the fourteen-week semester, as both researcher and subject, I had unlimited access to when data could be collected. So the contexts in which I found myself, both within the formal arrangements of the subject and in the activities of my life more broadly, provided diverse opportunities to learn about design. For example, as part of my academic life I attended public seminars where practising architects talked about their processes and projects. To keep track of and document my learning to design over the semester, I gathered various data including:

- Subject documentation such as subject outline, studio handouts and assessment guidelines

- Extensive audio recordings of lecture and studio sessions

- Notes I made during lecture and studio sessions

- Selective video recordings during studio sessions, including of other students' designing, when and if I felt it might help my own learning

- A journal in which I recorded extensive chronological field notes of my own thoughts, questions, observations and ideas as they occurred, and in such a way as not to disrupt the designing itself

- Design artefacts I made including drawings and models as well as digital photographs I took at various times to document consecutive development of my modelling

- Formal assessment submissions and formal written feedback

- Records of various related experiences outside of formal learning in Design Basics

- Video recordings of a series of four conversations held individually with students on completion of this subject to elicit their experiences and views of designing

Amassing a large, complex dataset, I developed a system to organize this data in such a way as to enable ready access, comparison, interrogation and referral.

As a learner-researcher, I used that data to track my own designing in the context of my class community's learning over time, how my architectural design ideas were tested and the nature of any progression that occurred in my thinking about design. Furthermore, to preserve the integrity of the research in its reporting, I organized the reporting of my findings according to the key milestones marked out as the subject assessments. As each milestone section of the account was written, I could analyse it for evidence of my ideas about design, focusing on my development and critique of those understandings of design. By attending to such detail, I was able to write a careful descriptive and analytical case study of my learning to design. As such, this extensive account was cumulative and developmental (see Golja 2011).

So, in this first-person study, I set out to investigate: What insights into design, if any, can I gain as a learner-researcher in an undergraduate architectural design basics subject? Design Basics was studio based, with students undertaking a project-based design exercise. During my participation this project involved designing a weekender for a particular client in a specified location and on a defined site. Here, I report the key findings of this learner-researcher study. 


\section{Gaining design knowledge through learning to design}

My analysis of data from the early weeks suggested to me that I had a view of designing as developing the fit of my building idea with the client's expressed needs and desires. To create this fit, it appeared to me that I was eliciting, analysing and enacting qualities important to this particular client.

In subsequent weeks, my analysis indicated that development of ideas over time were integral to designing. Indeed, it became increasingly clear to me that designing did not entail instructions, nor could the design be known a priori. Rather, ideas emerged as we were designing, and these ideas developed through testing, modifying and refining. I also began to recognize various contextual influences shaping my design ideas, factors that I was taking into account to enhance fit between the client's and my design ideas.

Over the final weeks, I was able to form a developmentally coherent view of designing as three phases, a view that made clear the changes in my ideas about designing over the semester. I identified and described these three phases through which I came to appreciate that my ideas about designing passed in this way:

\section{Imagining possibilities}

In learning to design I sought inspiration from various sources and in different ways. Designing encouraged me to be open to experiences, opportunities and changes, to observe my surroundings and to scout into new areas. Such explorations were driven by an enquiring urge that gave rise to copious questions over the 14 weeks. Once such questions were made explicit, I noticed that new ideas emerged to be explored and investigated for their fruitfulness, through engagement in a broad and rich communal setting. Such engagement occurred, for example, through,

- An iterative process of meeting with the client, exploring possibilities together in conversation;

- Analysing the site map, its particular topographical features, as well as using first hand experiences of the site's location;

- My own experience and access to the work of others, becoming aware of the pivotal role of media and technologies in designing;

- Comparing other students' interpretations of the same client's brief with my own, noting similarities and questioning differences;

- Immersion in the immediate physical environment, closely observing objects of importance or interest to us;

- Becoming familiar with the work of architects preceding us, recognizing this inherited pool of architectural ideas could be used to learn from, to think with and to generate contemporary possibilities;

- A growing awareness of diagrams and their potential as a generative technique;

- Considering the potential of ideas originating in disciplines outside Architecture, exploring by way of interpretation and experimentation; and,

- A seemingly insatiable curiosity in attempting to meet design challenges, and venturing beyond what I knew, for example, in exploring ideas about curvature that challenged square box housing. 
In all these ways, as we engaged with diverse opportunities, possibilities could be imagined.

\section{Interpreting ideas to form architectural principles}

I recognized design ideas in the studio setting had their roots in these early explorations and imaginings. Initial ideas were interpreted and represented in architectural terms, through form and shape. I noticed, as I experimented using various media, that modelling enabled greater fluency in my transition to working with ideas in spatial ways. From such interpretation and exploration, I generated curving forms.

From an initial curiosity about architectural design as a conceptual process, I came to understand architectural design as a particular way of carving up a space, where concepts in design were organizing principles or broad patterns. On that view, a concept organized and structured spatial thinking in designing. Once we had generated a concept for a particular project, questions and possibilities emerged that began to constrain the choices we could make and subsequently, how a building idea developed under contextual influences (developing fit with client and environment). In other words, we interpreted and tested various emerging ideas and influences against this concept for fit and relevance, and so, concepts acted as a useful constraint in our designing. I came to observe how concepts offered a rigorous way of thinking about a spatial idea, for exploring possibilities and guiding development.

Through my exploration of curvature, I sought to understand the spatial principles that could guide the development of such organic forms. I had organized and structured these curving spatial ideas so they expressed a sense of flow and movement, a welcoming gesture, as they encompassed the natural bush environment within their spaces. However, such structuring seemed to lack rigour. Though I did not know what spatial principles might shape curving forms in architectural designing, I speculated that these values would not originate from Euclidean spatial rules. I came to recognize that spatial principles were dynamic: that conceptual development in architectural designing was influenced by broader cultural knowledge and change, for example, of materials, technologies and theories. Such exploration of spatial ideas and concepts provoked insights into how designing development seemed to occur, in my own designing over one semester and in the discipline of Architecture over longer time spans.

\section{Distilling quality}

From one project brief, we were to generate many and diverse ideas over the course of our designing in this subject. In developing our design proposals, clearly we were selecting some ideas and discarding others, as were the teaching staff. Therefore, we were making value judgements (whether tacitly or explicitly) about the ideas we were generating and the choices we were making: for example, what was good about particular ideas, what was not; what was working, what was not. In our designing, as these selections seemed to be made for their particular worth or value, our design ideas developed in particular ways: through processes of analysing and testing these values, modifying and rethinking, refining and making changes.

In the first week of my learning to design, I wondered how the conceptual process in architectural designing occurred. Much later, serendipitous events exposed me to various broader conceptual shifts that had influenced Architecture. I came to understand knowledge, in itself, as value choices, and so, such conceptual shifts represented value change or development. Similarly, in our designing over the 14 
weeks, our design concepts also underwent many changes; their qualities were tested in various ways and developed. For example, our early design ideas aimed to develop initial fit with the client and we took a proactive approach to elicit, analyse and enact values important to our client. Then, I began to conceive how contextual influences could enhance this fit between the client's and my design ideas. In such development over time, our design ideas were subject to tests and from such tests we could begin to generate criteria for being able to recognize the quality of our design choices. For example, I reviewed the client's and the tutor's responses to my design idea and clearly, I took their value judgments into account in my subsequent design decisions; my early investigation into curvature had seeded questions about judging quality; and, perhaps most poignantly for me, when I could not generate the architectural criteria on which to judge my curving design idea, I radically changed my design concept. I adopted a new concept which, when subsequently put to architectural tests for quality, failed.

On this view of designing, I came to recognize that when the academic teacher discussed our learning to design, he was actually describing a process of distilling quality over time. He provoked us to consider why we were designing in the way we were and the choices we were making. He urged us to interrogate the architectural ideas we were inheriting, as Venturi did in challenging modernist values with their absence of cultural meaning and contextual relationship. He took opportunities to expose us to how, historically, architects had imbued their architectural designs with particular qualities: for example, values such as beauty, form, emotional effect. So, I came to understand how, through designing, such broad values were interpreted to form coherent, rigorous architectural principles. We were encouraged in our designing to interrogate how different qualities might be conceived and evaluated and subsequently, how we might test the architectural interpretation of the value itself. In essence, it seemed to me that criteria surfaced during the process of designing for, in that dynamic context, values could be examined, and re-examined, over time.

So I came to understand that designing intimately concerned the quality of what was designed, quality that was distilled over time: so designing was not only about a process, about development or reaching a solution. Rather, designing involved making explicit why particular choices or decisions were selected as values and realized and it involved judging quality by testing in the physical and social world. Of course, quality could be judged solely on internal criteria (what the academic teacher termed "selfreferential": testing that occurred against geometrical criteria). However, this selfreferential testing seemed to signal a deficit view of architectural design, lacking external value tests. Paradoxically, such designing failed the most fundamental tests of quality at the individual and collective (or societal) levels (for example, designing could ignore the client's core desires, as some students had done when they unsuccessfully presented their initial design ideas to the client).

Essentially, then, by being a learner-researcher in an undergraduate architectural design basics subject and progressing my views of designing over the weeks of studying this subject, I was able to refine my view of architectural designing to develop a threepart heuristic of imagining possibilities, interpreting ideas to form architectural principles and distilling quality (Figure 1). As such, this view of architectural designing is a heuristic for value selection. 


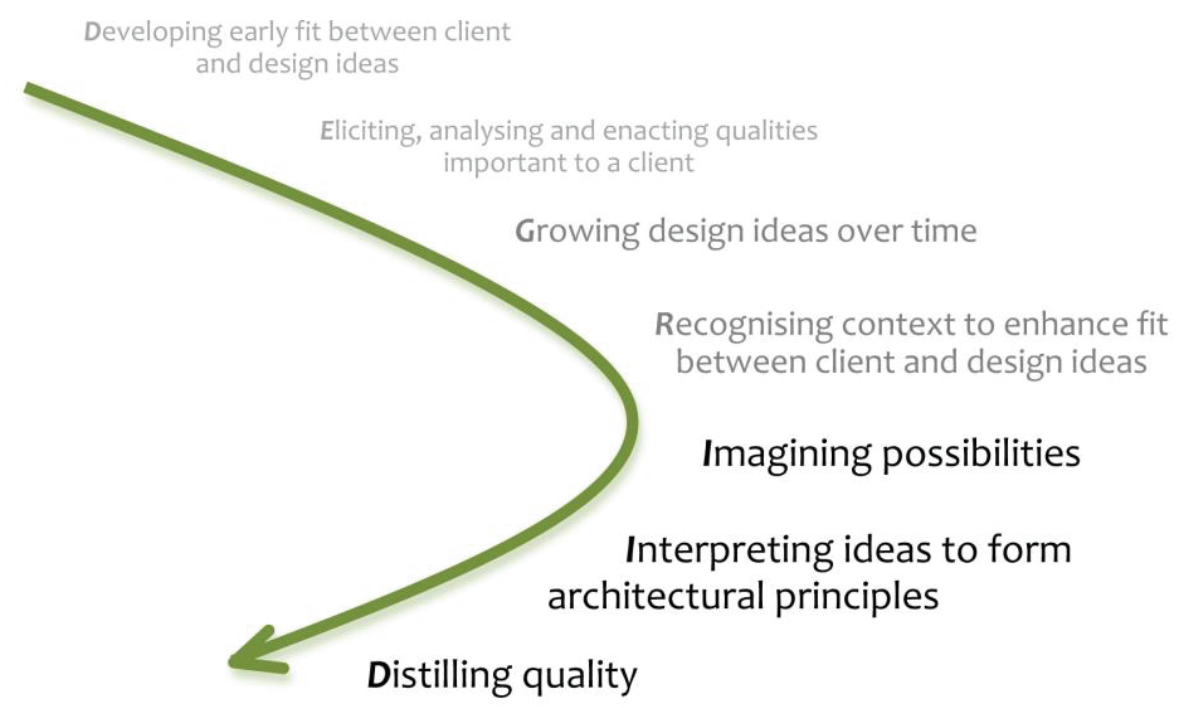

Figure 1. My value selection heuristic of architectural designing. Source: Golja 2011.

The detailed evidence of this learner-researcher account legitimizes such a view of designing and the idiosyncratic pathway by which it crystallized. However, it was then necessary to test its broader viability. I did so by analysing whether this particular design knowledge, gained through learning to design, could also describe and explain architectural designing more broadly.

\section{Testing the viability of my design knowledge}

So as to perform a preliminary, small-scale test of the viability of my value-selection design heuristic, I selected a small number of recent cases of architectural designing, conceived and realized at the cusp of the twenty-first century, where I could access designs and design development by way of extensive archival material (including commentary on designing events from different perspectives). So that my small set of test cases might be as representative and diverse as possible, I decided to include architectural designs with different cultural and environmental contexts, different uses or functions and different project scales. Based on this criteria, three cases were chosen: Beijing's National Aquatic Centre for the 2008 Olympic Games (the Watercube); 30 St Mary Axe, London; the Modern Education and Training Institute (METI) School, Rudrapur.

There were obvious constraints and limitations of this archival approach. For example:

- I could access only selective and, in some places, fragmented and necessarily subjective records of designing as development over time.

- Accounts might have been written retrospectively thereby neglecting possibly significant fine-grained detail while designing was occurring, at best possibly jeopardizing chronological accuracy, and at worst, risking presenting a different story.

- The discourse of professional architectural designing might have masked the struggle that such human activity encompassed and instead, may have emphasized particular successes or failures as end points. 
Nevertheless, from the detailed and rich archival data available for these three cases, I could track development using both designing events and design artefacts to write detailed case studies (see Golja 2011). From those accounts, I gauged whether such designing could be recognized as value selection. What follows is a brief analytical summary.

\section{National Aquatic Centre, Beijing}

The design of the National Aquatic Centre for the 2008 Olympic Games had its genesis in playful exploration of the fundamental element of an aquatic environment: water. The state of water became an inspiration for organic curvilinear forms, wall features, entrances and cladding. However, given the cultural location of this Olympic venue, traditional Chinese geometries of axial arrangement and rectilinearity were deemed important and explored in relation to this Aquatic Centre's historical precinct. Clearly, the Watercube designers imagined possibilities.

Key contextual factors (such as light, heat, acoustics) were subsequently identified, influences against which these early ideas of water and square form could be further tested. Indeed, such influences provoked ideas about an insulated greenhouse with its structure in a cavity and ETFE as cladding material. As design ideas were being investigated and refined, the choice of an innovative structure became crucial. A novel structural system incorporating space and façade was conceived architecturally from previous design explorations of bubbles and recent concepts derived from theoretical physics. So these designers interpreted crucial ideas to form architectural principles. As they tested their evolving imaginative and architectural ideas against various contextual and cultural factors, they distilled quality in their developing architectural concept which went on to receive public recognition and be awarded the winning entry in this prestigious Olympic design competition.

Throughout this contingent, iterative process of the Watercube's early designing over time, evidently, different possibilities emerged and were explored and tested architecturally, before being selected on the basis of their value. In essence, I could recognize the designing of the Watercube as a case of value selection.

\section{30 St Mary Axe, London}

The historic site of 30 St Mary Axe created particular architectural opportunities, bringing together three distinctive agendas. The historical significance of an urban setting, a client's drive for innovation and sustainability and an architectural firm's conceptual development of ideas (articulated and realized in their previous projects) acted to ignite early imaginative possibilities for a skyscraper.

Initially, client-based desires and aspirations shaped the architects' form-finding experiments, generating non-conventional complex forms. Social spaces, a key design priority for this architectural firm, were then explored as atria in those forms and such ideas were shaped aesthetically by economic considerations. Over time, curvaceous forms, a spiralling language generated by rotating atria, viable construction of floor plates and a simple complementary structural logic emerged as architects explored and interpreted various social, environmental and economic agendas to fuel ongoing design progression and new possibilities.

Parametric modelling enabled designers to create and test dynamic models to better understand the qualities of these complex geometries. As testing occurred on these developing architectural ideas, particular aesthetic principles were also explored, selected and refined to distil quality. For example, qualities initially tested intuitively 
were then examined technologically as parameters for elegant curvaceous forms, for ecological benefits, for a feasible structural system and for an economically viable program.

Again, this second case of designing resembles a value-selection view of design. In developing the concept for 30 St Mary Axe through intensive modelling, various agendas were taken into consideration to trigger innovative possibilities. Such values were interpreted as, for example, aesthetic principles in form, structure and program. These qualities were then refined when design ideas underwent further tests (for example, of feasibility, viability, sustainability and profitability) and were modified. Therefore, in this second case, I can also recognize designing as value selection.

\section{Modern Education and Training Institute (METI), Rudrapur}

The design of the METI School arose from a series of fortuitous events. An architecture student's early experiences in a foreign community awakened particular cultural sensitivities. Then, opportunities in her architectural studies enabled continuing pursuit of her interests and concerns for this community through designing, in particular, a school. In these fertile environments, possibilities emerged and were imagined.

As she designed the school, this student identified qualities important to the village community, the local educational system (METI) and the children. She explored these qualities architecturally against a wash of her own personal views and experiences. For example, having articulated a concept of beauty as sustainability and harmony with the ecosystem, she used this concept to re-examine the use of local materials and resources. For her, designing involved generating fit between the community's desires and their ecological sustainability (including economic self-sufficiency and environmental balance). So, in reconceiving endogenous resources (mud, bamboo) and generating a novel structure in collaboration with another architect, she clearly interpreted ideas gained from her cultural and educational experiences to form architectural principles. Once such design principles were deemed to have been successfully enacted in the METI School, they were utilized by the community in other building projects. So, in designing to respect the sustained growth of local identity, testing her architectural ideas against various cultural responses and support of a community's development, she distilled quality.

The METI School and the designs it subsequently generated also illustrate how the process of values development can occur in designing. Cultural qualities were made explicit and examined. An imaginative, architectural re-interpretation of such qualities generated new principles for designing. These principles provoked value change in a community and the creation of a new knowledge system. (For example, children were learning in a built environment that itself was an innovative embodiment of new community values; more broadly, the community used the new architectural principles to drive their own development.) This third case affirmed designing as value selection.

Just as my view of designing anticipates a developmental pathway (shown in Figure 1), influenced by contextual factors and individual agendas, so too, the designing in each of these three cases, through responding to various influences and opportunities, set distinctive trajectories. Furthermore, in each unique case, a value-selection heuristic could describe and explain how designing occurred. Therefore, the evidence I found suggests that a view of designing as value selection was viable in contemporary architectural designing (to the extent that these three cases represented it). 


\section{Conclusion}

Of the wide range of possible research approaches to gain design knowledge, a learner-researcher approach was ideally suited for me, as an educator, to be able to gain insights about design in an unfamiliar discipline. Indeed, just as I had engineered a methodology to undertake research outside my field of expertise, so too have other scholars undertaking design research: for example, Lyon's $(2009,2011)$ studies, as an "outsider" researcher, in the Centre for Excellence in Teaching and Learning through Design (CETLD), illustrating how it is possible to engineer a range of different methodologies appropriate to the circumstances of particular researchers. I was able to locate one other leaner-researcher study in an educational setting (McGinn and Boote 2003), although the learner-researchers in that study were not novices, as I was, but expert mathematicians who chose to study problem solving by enrolling in an undergraduate history of mathematics subject.

In my study, I acknowledge that I could only approximate the experience of a real student. (For example, I was only studying one subject and could not benefit from complementary insights from other subjects as other students did; and no matter how genuinely I tried to assume the role of a student, the subject teaching team was aware, in the final analysis, that I was not a student.) Nevertheless, I believe that the approach had integrity in that I was and felt that I was, in every sense, a learner in this subject context and the subject teaching team, as well as other learners, could see that I was. Though this methodology can be demanding, further learner-researcher studies, where such an approach has integrity for researchers, would complement the single perspective I have reported here and provide further valuable insights for academics and for professional practitioners.

As already noted, I am not a designer nor an architect, although I have undertaken a preliminary test of my view of designing as value selection by consulting available accounts of three recent architectural designs. Other studies, undertaken in different architectural contexts, have also viewed designing as having an important valuing component (for example, Beinart 1981a, 1981b; Billings and Akkach 1992; Lera 1981; Loukissas 2008). Design scholars might now examine my view of designing to see if they agree with it or whether it needs to be modified or extended. In fact, design scholars may wish to revisit the findings of these two studies as set out in my data (Golja 2011) to see if they affirm, reject, modify or extend my interpretations. Such undertakings could provide fruitful ways of triangulating and/or corroborating the design knowledge I gained through these two studies. These suggested research directions could also provide these scholars with valuable learning, teaching and research data.

At core, my value selection heuristic - in which I crystallized the three components of imagining possibilities, interpreting ideas to form (architectural) principles and distilling quality - attempts to explain how designing occurs, and thereby lays the ground for theory development. Here, in my learner-researcher study, I reported on development (or progression) in designing. To do so, I engineered and used a research approach that sought to detect designing development as it occurred over real time. Other researchers in various designing disciplines have chosen to gain insight into development in a different way: by investigating specific snapshots of development novices, design graduates or expert designers - and comparing the designing of these different populations (for example, Atman, Chimka, Bursic and Nachtmann 1999; Bonnardel and Marmèche 2004; Kavakli and Gero 2002; Seitamaa-Hakkarainen and Hakkaraninen 2001). Now, overarching developmental explanations of designing are 
needed that will go some way towards unifying research findings from these differing approaches. Whilst it is difficult to induce a resilient theory from my developmental data, on its own, my investigation can provide a small exemplar of how such data, required for theorizing, might be collected and analysed for explanatory insights in diverse design and educational contexts.

Acknowledgements: The first author is especially thankful to Associate Professor Steve Harfield for the privilege of learning about design in the innovative and vibrant educational environment of his architectural design subject. She is also grateful for the generosity and openness of students and tutors in this undergraduate subject who made her feel part of their learning community and from whom she learned much about designing. Finally, it was only through the Faculty of Design, Architecture and Building's recognition of the value of this doctoral investigation and our shared aspirations to understand design education much more deeply that it was able to proceed.

\section{References}

Altman, Lawrence. 1987. Who goes first? The story of self-experimentation in medicine. New York: Random House.

Assessment Procedures Manual UTS. 2001/2010 [cited November 15 2012]. Available from http://www.gsu.uts.edu.au/policies/documents/assessment-courseworkprocedures.pdf.

Atman, Cynthia, Justin Chimka, Karen Bursic, and Heather Nachtmann. 1999. "A comparison of freshman and senior engineering design processes." Design Studies 20(2): 131-152. doi:10.1016/S0142-694X(98)00031-3

Beinart, Julian. 1981a. "Analysis of the content of design." In Architectural education study - Volume I: The papers, edited by William Porter and Maurice Kilbridge, 3-157. Cambridge, MA: Consortium of East Coast Schools of Architecture. Supported by the Andrew W. Mellon Foundation.

Beinart, Julian. 1981b. "Structure of the content of design." In Architectural education study - Volume I: The papers, edited by William Porter and Maurice Kilbridge, 159338. Cambridge, MA: Consortium of East Coast Schools of Architecture. Supported by the Andrew W. Mellon Foundation.

Benton, Sarah. 2008. "The architectural designer and their digital media." PhD diss., RMIT University. Available from http://researchbank.rmit.edu.au/view/rmit:10013.

Billings, Keith, and Samer Akkach. 1992. "A study of ideologies and methods in contemporary architectural design teaching: Part 1: Ideology." Design Studies 13(4): 431-450. doi:10.1016/0142-694X(92)90171-6

Björklund, Tua. 2013. "Initial mental representations of design problems: Differences between experts and novices." Design Studies 34(2): 135-160. doi:10.1016/j.destud.2012.08.005.

Bonnardel, Nathalie, and Evelyne Marmèche. 2004. "Evocation processes by novice and expert designers: Towards stimulating analogical thinking." Creativity and Innovation Management 13(3): 176-186. doi: 10.1111/j.0963-1690.2004.00307.x

Bucciarelli, Louis. 1994. Designing engineers. Cambridge MA: MIT Press. 
Clements, Peter. 1999. "Autobiographical research and the emergence of the fictive voice." Cambridge Journal of Education 29(1): 21-32. doi:10.1080/0305764990290103

Cross, Nigel, and Anita Clayburn Cross. 1996. "Winning by design: The methods of Gordon Murray, racing car designer." Design Studies 17(1): 91-208. doi:10.1016/0142-694X(95)00027-0

Foster, Norman. 2007. Building on the green agenda [cited November 15 2012]. Available from http://www.ted.com/talks/norman_foster_s_green_agenda.html.

Foster and Partners. 2005. Catalogue. London: Prestel Verlag.

Golja, Tanja. 2011. "Addressing the challenge of educational design: Insights from Architecture and Architectural Design Education." PhD diss., University of Technology, Sydney.

Gregory, Rob. 2003. "Wind sock." The Architectural Review (London) 214(1281): 69-73.

Hensel, Michael, and Achim Menges, eds. 2006. Morpho-ecologies. London: Architecture Association.

Hensel, Michael, and Achim Menges. 2008a. "Inclusive performance: Efficiency versus effectiveness: Towards a morpho-ecological approach for design." Architectural Design 78(2): 54-63. doi:10.1002/ad.642

Hensel, Michael, and Achim Menges. 2008b. "Membrane spaces." Architectural Design 78(2): 74-79. doi:10.1002/ad.644

Hwang, Irene, Tomoko Sakamoto, Albert Ferré, Michael Kubo, Noorie Sadarangani, Anna Tetas, Mario Ballesteros, and Ramon Prat. 2006. "30 St. Mary Axe, Swiss Re Headquarters: Foster + Partners." In Verb natures, edited by Irene Hwang et al, 5053. Barcelona: Actar.

Jenkins, David, ed. 2002. Norman Foster works 1. London: Prestel Verlag. Jenkins, David, ed. 2004. Norman Foster works 4. London: Prestel Verlag. Jenkins, David, ed. 2007. Foster 40: Themes and projects. Munich: Prestel Verlag. Jenkins, David, ed. 2009. Norman Foster works 5. London: Prestel Verlag. Kavakli, Manolya, and John Gero. 2002. "The structure of concurrent cognitive actions: A case study on novice and expert designers." Design Studies 23(1): 25-40. doi:10.1016/S0142-694X(01)00021-7

Kelly, Anthony. 2009. "In defence of anonymity: Rejoining the criticism." British Educational Research Journal 35(3): 431-445. doi:10.1080/01411920802044438

Lancy, David. 1993. Qualitative research in education: An introduction to the major traditions. New York: Longman.

Lawson, Bryan. 1990. How designers think. Oxford: Butterworth Architecture.

Lawson, Bryan. 1994. Design in mind. Oxford: Butterworth Architecture.

Lera, Sebastian. 1981. "Architectural designers' values and the evaluation of their designs." Design Studies 2(3): 131-137. doi: 10.1016/0142-694X(81)90067-3

Loukissas, Yanni. 2008. "Conceptions of design in a culture of simulation." PhD diss., Massachusetts Institute of Technology.

Lyon, Philippa. 2009. "Writing about design pedagogy and designing pedagogical writing." Art, Design \& Communication in Higher Education 8(2): 151-156. doi:10.1386/adch.8.2.151/1

Lyon, Philippa. 2011. Design education: Learning, teaching and researching through design. Burlington: Gower.

Martinelli, Paul, Adam Czelusta, and S. Ray Peterson. 2008a. "Self-experimenters in medicine: Heroes or fools? Part I: Pathogens." Clinics in Dermatology 26: 570-573. doi:10.1016/j.clindermatol.2007.07.005 
Tanja Golja and Lynette Schaverien

Martinelli, Paul, Adam Czelusta, and S. Ray Peterson. 2008b. "Self-experimenters in medicine: Heroes or fools? Part II: Anesthesia, surgery, therapeutics, vaccinations, and vitamin C." Clinics in Dermatology 26: 657-661. doi:10.1016/j.clindermatol.2007.07.006

McGinn, Michelle, and David Boote. 2003. "A first-person perspective on problem solving in a history of mathematics course." Mathematical Thinking and Learning 5(1): 71-107. doi:10.1207/S15327833MTL0501_03

Nespor, Jan. 2000. "Anonymity and place in qualitative inquiry." Qualitative Inquiry 6(4): 546-569. doi:10.1177/107780040000600408

Pedgley, Owain. 2007. "Capturing and analysing own design activity." Design Studies 28(5): 463-483. doi:10.1016/j.destud.2007.02.004

Porter, William, and Maurice Kilbridge, eds. 1981a. Architectural education study Volume I: The papers. Cambridge, MA: Consortium of East Coast Schools of Architecture. Supported by the Andrew W. Mellon Foundation.

Porter, William, and Maurice Kilbridge, eds. 1981b. Architectural education study Volume II: The cases. Cambridge, MA: Consortium of East Coast Schools of Architecture. Supported by the Andrew W. Mellon Foundation.

Powell, Kenneth. 2006. 30 St Mary Axe: A tower for London. London: Merrell Publishers Limited.

Schön, Donald. 1981. "Learning a language, learning to design." In Architectural education study - Volume I: The papers, edited by William Porter and Maurice Kilbridge, 339-471. Cambridge, MA: Consortium of East Coast Schools of Architecture. Supported by the Andrew W. Mellon Foundation.

Schön, Donald. 1983. The reflective practitioner: How professionals think in action. New York: Basic Books.

Schön, Donald. 1984. "The architectural studio as an exemplar of education for reflection-in-action." Journal of Architectural Education 38(1): 2-9. http://www.jstor.org/stable/1424770.

Schön, Donald. 1985. The design studio: An exploration of its traditions and potentials. London: Royal Institute of British Architects.

Schön, Donald. 1987. Educating the reflective practitioner. San Francisco: Jossey-Bass Publishers.

Seitamaa-Hakkarainen, Pirita, and Kai Hakkaraninen. 2001. "Composition and construction in experts' and novices' weaving design." Design Studies 22(1): 47-66. doi:10.1016/S0142-694X(99)00038-1

SIAL, RMIT. 2006. Embedded research within architectural practice [cited November 15, 2012]. Available from http://www.sial.rmit.edu.au/Projects/Embedded_Research_within_Architectural_Pr actice.php.

Simmonds, Roger. 1981. "Case a: A first year studio in a graduate school of architecture." In Architectural education study - Volume II: The cases, edited by William Porter and Maurice Kilbridge, 5-206. Cambridge, MA: Consortium of East Coast Schools of Architecture. Supported by the Andrew W. Mellon Foundation.

Stacey, Michael, cur. 2004. Digital fabricators [cited November 15 2012]. Available from http://www.formpig.com/pdf/formpig_digital\%20fabricators\%20catalogue_acadia.p df.

Sunguroglu, Defne. 2008. "Complex brick assemblies." Architectural Design 78(2): 6473. doi:10.1002/ad.643 
Tilley, Liz, and Kate Woodthorpe. 2011. "Is it the end for anonymity as we know it? A critical examination of the ethical principle of anonymity in the context of $21^{\mathrm{st}}$ century demands on the qualitative researcher." Qualitative Research 11(2): 197212. doi:10.1177/1468794110394073

Vinck, Dominique, ed. 2003. Everyday engineering: An ethnography of design and innovation. Cambridge, MA: MIT Press.

von Arx, Mirjam (Executive producer/Director), and Patrick Müller (Executive producer). 2006a. Building the Gherkin [DVD]. Zurich, Ican films.

von Arx, Mirjam (Executive producer/Director), and Patrick Müller (Executive producer). 2006b. "Robin Partington's architectural masterclass." Building the gherkin. Zurich, Ican films.

von Arx, Mirjam (Executive producer/Director), and Patrick Müller (Executive producer). 2006c. "Norman Foster in conversation." Building the gherkin. Zurich, Ican films.

von Buttlar, Florian. 1981. "Case y: An intermediate level studio in a graduate school of architecture." In Architectural education study - Volume II: The cases, edited by William Porter and Maurice Kilbridge, 207-596. Cambridge, MA: Consortium of East Coast Schools of Architecture. Supported by the Andrew W. Mellon Foundation.

Walford, Geoffrey. 2005. "Research ethical guidelines and anonymity." International Journal of Research \& Method in Education 28(1): 83-93. doi:10.1080/01406720500036786

Yaneva, Albena. 2005. "Scaling up and down: Extraction trials in architectural design." Social Studies of Science 35(6): 867-894. doi:10.1177/0306312705053053.

Yaneva, Albena. 2006. Made by the Office for Metropolitan Architecture: An ethnography of design. Rotterdam: 010.

Yaneva, Albena. 2009. The making of a building: A pragmatist approach to architecture. Bern: Peter Lang. 


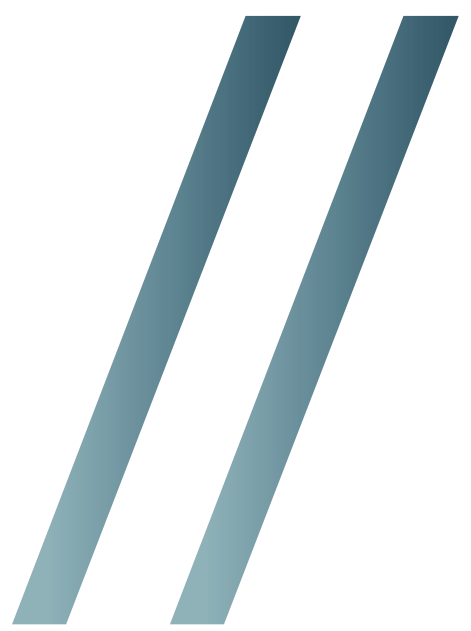

\section{DRS \\ CUMULUS \\ Oslo 2013}

\section{Design Learning for Tomorrow}

Design Education from Kindergarten to PhD

\section{Proceedings from}

the 2nd International Conference

for Design Education Researchers,

14-17 May 2013, Oslo, Norway 


\title{
Proceedings of the $2^{\text {nd }}$ International Conference for Design Education Researchers
}

\author{
14-17 May 2013, Oslo, Norway \\ Volume 2
}

Editors

Janne Beate Reitan

Peter Lloyd

Erik Bohemia

Liv Merete Nielsen

Ingvild Digranes

Eva Lutnæs 
Conference identity design by Monika Hestad and Ingvild Digranes

Paper layout design by Ole Lund, University of Reading and Gjøvik University College Proceedings compiled by Eva Lutnæs

Editorial arrangements by Janne Beate Reitan, Peter Lloyd, Erik Bohemia, Liv Merete Nielsen, Ingvild Digranes and Eva Lutnæs

C2013 ABM-media and the Authors. All rights reserved

ISBN 978-82-93298-00-7 (vol.1-4)

ISBN Volume 1 978-82-93298-01-4 (print)

ISBN Volume 2 978-82-93298-02-1 (print)

ISBN Volume 3 978-82-93298-03-8 (print)

ISBN Volume 4 978-82-93298-05-2 (print)

ISBN Volumes 1-4 978-82-93298-04-5 (electronic)

Published by ABM-media as

c/o Oslo and Akershus University College of Applied Sciences

v/Hans Martin Fagerli

PO Box 4 St Olavs plass, 0130 Oslo, Norway

email: post@abm-media.no

www.abm-media.no

Print office: Allkopi

Design Research Society

DRS Secretariat

email: admin@designresearchsociety.org

www.designresearchsociety.org

CUMULUS the International Association of Universities and Colleges of Art, Design and Media

Cumulus Secretariat

Aalto University School of Arts, Design and Architecture

PL 31000, 00076 Aalto, Finland

Secretary General Eija Salmi

Tel: +358505927060

email: eija.salmi@aalto.fi

www.cumulusassociation.org

Oslo and Akershus University College of Applied Sciences

Faculty of Technology, Art and Design

PO Box 4 St Olavs plass, 0130 Oslo, Norway

www.hioa.no/eng/Om-HiOA/The-Faculty-of-Technology-Art-and-Design

LEGAL NOTICE: The publisher is not responsible for the use which might be made of the following information. 
This conference proceedings version was produced on 23 April 2013

The DRS//CUMULUS 2013 Oslo conference was hosted and organised by Oslo and Akershus University College of Applied Sciences with the support from: DRS PedSIG, CUMULUS, HEA, Gjøvik University College, Université de Montréal, Aalto University, Oslo School of Architecture and Design, Open University, Coventry University, Politechnico di Milano, École Parsons Á Paris, L'école de Design Nantes Atlantique, and Loughborough University

\section{Patrons of the Conference}

Dean Petter $\varnothing$ yan, Oslo and Akershus University College of Applied Sciences, Norway Prof. Michael Tovey, DRS, Coventry University, UK

President Christian Guellerin, CUMULUS, L'Ecole de design Nantes Atlantique, France

\section{Conference Chair}

Prof. Liv Merete Nielsen, Oslo and Akershus University College of Applied Sciences, Norway

\section{Conference co-Chairs}

Dr. Erik Bohemia, DRS, Loughborough University; UK

Prof. Luisa Collina, CUMULUS, Politicnico di Milano; Italy

Assoc. Prof. Janne Beate Reitan, FORMakademisk, Oslo and Akershus University College of Applied Sciences, Norway

\section{Scientific Review Committee}

Prof. Peter Lloyd, DRS, Open University, UK (chair)

Assoc. Prof. Janne Beate Reitan, FORMakademisk, Oslo and Akershus University College of Applied Sciences, Norway (co-chair)

Prof. Tiiu Poldma, Université de Montréal, Canada

Prof. Birger Sevaldson , Institute of Design, Oslo School of Architecture and Design, Norway

Assoc. Prof. Ole Lund, Gjøvik University College, Norway and Reading University, UK Assoc. Prof. Ingvild Digranes, TechneA, Oslo and Akershus University College of Applied Sciences, Norway

Prof. Weiqin Chen, Oslo and Akershus University College of Applied Sciences, Norway Prof. Eddie Norman, Design and Technology Education, Loughborough University, UK Prof. Linda Drew , Art, Design \& Communication in Higher Education, Glasgow School of Arts, UK

Dr. Brigitte Borja de Mozota, Parsons Paris School of Art and Design, France Dr. Erik Bohemia, Loughborough University, UK Prof. Liv Merete Nielsen, Oslo and Akershus University College of Applied Sciences, Norway 


\section{International Review Board}

Cheryl Akner-Koler, Konstfack University College of Arts, Crafts and Design, Sweden Robert Arens, Cal Poly, United States

Trygve Ask, Scandinavian Business Seating Group AS, Norway

Petra Badke-Schaub, TU Delft, Netherlands

Steen Ory Bendtzen, Oslo and Akershus University College of Applied Sciences, Norway

Gerd Berget, Oslo and Akershus University College, Norway

bernadette BLAIR, Kingston University - London, United Kingdom

Per Boelskifte, DTU Technical University of Denmark, Denmark

Erik Bohemia, Loughborough University, United Kingdom

Elivio Bonollo, University of Canberra, Australia

Kaisa Borg, University of Umeå, Sweden

Jorunn Spord Borgen, Norwegian School of Sport Sciences, Norway

Brigitte Borja de Mozota, Paris College of Art ( PCA) (ex Ecole Parsons à Paris ), France

Carole Bouchard, Ecole Nationale Supérieure d' Arts et Métiers, France

Han Brezet, TU Delft, Netherlands

Hernan Casakin, Ariel University Center, Israel

Weiqin Chen, Oslo and Akershus University College, Norway

Peter Childs, Imperial College London, United Kingdom

Priscilla Chueng-Nainby, The Glasgow School of Art, United Kingdom

Susan Close, University of Manitoba, Canada

Alma Culen, University of Oslo, Norway

Giovanni De Paoli, University of Montreal, Canada

Gaurang Desai, American University of Sharjah, United Arab Emirates

Ingvild Digranes,, Oslo and Akershus University College of Applied Sciences, Norway

Monica Divitini, Norwegian University of Science and Technology, Norway

Linda Drew, Glasgow School of Art, United Kingdom

Mary Clare Dyson, University of Reading, United Kingdom

Nada El-Khoury, Lebanese American University, Beirut, School of Architecture \& Design, Lebanon

Mark Evans, Loughborough University, United Kingdom

Akar Evren, METU, Turkey

Nuša Fain, University of Strathclyde, United Kingdom

Laila Belinda Fauske, Telemark University College, Norway

Salustri Filippo A., Ryerson University, Canada

Tom Fisher, Nottingham Trent University, United Kingdom

Jill Franz, Queensland University Technology, Brisbane, Australia

Biljana C. Fredriksen, Vestfold University College, Norway

Philippe Gauthier, University of Montreal, Canada

Aysar Ghassan, Nortumbria University, United Kingdom

Jacques Giard, Arizona State University, United States

Carma R. Gorman, Southern Illinois University Carbondale, United States

Hilary Grierson, University of Strathclyde, United Kingdom

Tore Gulden, Oslo and Akershus University College, Norway

Marte Sørebø Gulliksen, Telemark University College, Norway

Young-ae Hahn, Aalto University School of Arts, Design and Architecture, Finland

Else Marie Halvorsen, Telemark University College, Norway

Michael Ulrich Hensel, Oslo School of Architecture and Design, Norway

Monika Hestad, Central Saint Martins College of Art and Design, United Kingdom

Clive Hilton, Open University, United Kingdom

JanWillem Hoftijzer, Delft University of Technology, Netherlands

Annelie Holmberg, Uppsala University, Sweden

Berit Ingebrethsen, Telemark University College, Norway 
Konstantinos loannidis, University of Stavanger, Norway

Bill Ion, University of Strathclyde, United Kingdom

Praima Israsena, Chulalongkorn University, Thailand

Eivind Arnstein Johansen, Gjøvik University College, Norway

Derek Jones, The Open University, United Kingdom

Guy Julier, University of Brighton, United Kingdom

Victor Kaptelinin, University of Bergen, Norway

Martina Keitsch, Norwegian University of Science and Technology (NTNU), Norway

Yong Se Kim, Sungkyunkwan University, South Korea

KwanMyung Kim, UNIST, Ulsan National Insitute of Sciences and Technology, South Korea

Michael K. Kim, University of Illinois at Urbana-Champaign, United States

Ahmed Kovacevic, City University London, United Kingdom

Blair Kuys, Swinburne University of Technology, Australia

Grace Lees-Maffei, University of Hertfordshire, United Kingdom

Gerry Leonidas, University of Reading, United Kingdom

Andre Liem, Norwegian University of Science and Technology, Norway

Debra Lilley, Loughborough University, United Kingdom

Blaine Lilly, Ohio State University, United States

Viveca Lindberg, University of Stockholm,, Sweden

Peter Lloyd, The Open University, United Kingdom

Maria Cecilia Loschiavo dos Santos, University of Sao Paulo, Brazil

Jennifer Loy, Griffith University, Australia

Ole Lund, University of Reading, United Kingdom

Eva Lutnæs, Høgskolen i Oslo og Akershus, Switzerland

Esko Mäkelä, University of Umeå, Sweden

Janet Theresa McDonnell, Central Saint Martins, United Kingdom

Punya Mishra, Michigan State University, United States

C.Thomas Mitchell, Indiana University, United States

Liv Mjelde, Oslo and Akershus University College, Norway

Ravi Mokashi Punekar, Indian Institute of Technology, Guwahati, India

Anders Mørch, University of Oslo, Norway

Andrew Morrison, Oslo School of Architecture and Design, Norway

Jeanne-Louise Moys, University of Reading, United Kingdom

Yukari Nagai, Japan Advanced Institute of Science and Technology, Japan

Liv Merete Nielsen, Oslo and Akershus University College, Norway

Fredrik Nilsson, Chalmers University of Technology, Sweden

Nithikul Nimkulrat, Loughborough University, United Kingdom

Eddie Norman, Loughborough University, United Kingdom

Leikny Øgrim, Oslo and Akershus university College, Norway

Jane Osmond, Coventry University, United Kingdom

Oscar Person, Aalto University / TU Delft, Finland

Tiiu R Poldma, University of Montreal, Canada

Mia Porko-Hudd, Åbo Akademi, Finland

Viriya Pungthong, Chulalongkorm University, Thailand

Janne Beate Reitan, Oslo and Akershus University College of Applied Sciences, Norway

Erik Reviewer, Loughborough University, United Kingdom

Mariana Rachel Roncoletta, Sao Paulo, Brazil

Bonnie Sadler Takach, University of Alberta, Canada

Norun Christine Sanderson, Oslo and Akershus University College, Norway

Gaia Scagnetti, Chulalongkorm University, Thailand

Nicole Schadewitz, Open University, United Kingdom

Pirita Seitamaa-Hakkarinen, Helsinki University, Finland

Birger Sevaldson, Oslo School of Architecture and Design, Norway

Alison Shreeve, Buckinghamshire New University, United Kingdom 
Beata Sirowy, University of Life sciences, Norway

Astrid Skjerven, Akershus University College, Norway

Liliana Soares, Polytechnic Institute of Viana do Castelo, Portugal

Kay Stables, Goldsmiths, University of London, United Kingdom

Pim Sudhikam, Chulalongkorn University, Thailand

Kärt Summatavet, Estonian Academy of Arts, Estonia

Yasuko Takayama, Shizuoka University of Art and Culture, Japan

Nanci Takeyama, Nanyang Technological University, Singapore

Kevin Tavin, Aalto University, Finland

Mike Tovey, Coventry University, United Kingdom

Maiko Tsutsumi, Camberwell College of Arts, University of the Arts London, United Kingdom

Lisa Tucker, Virginia Tech, United States

Annemiek van Boeijen, TU Delft, Netherlands

Robin Sue Vande Zande, Kent State University, United States

Soumitri Varadarajan, RMIT University, Australia

Guillermo Vega-Gorgojo, University of Valladolid, Spain

Johan Verbeke, LUCA, Belgium

Sue Walker, University of Reading, United Kingdom

David Wang, Washington State University, United States

Fabiane Wolff, UniRitter - Laureate International Universities, Brazil

Mithra Zahedi, University of Montreal, Canada 


\section{Table of Contents}

\section{Introductions}

Design Learning for Tomorrow - Design Education from Kindergarten to PhD

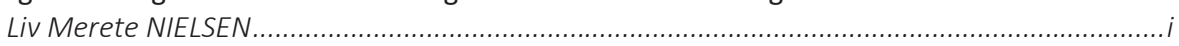

Design Pedagogy Special Interest Group of DRS Michael TOVEY.

About the Design Research Society Christian GUELLERIN

\section{- Volume 1 - \\ Design Curriculum}

$I C T$, ideation pedagogy and Innovation Education: setting a new paradigm in graphic design education Edward APPIAH, Johannes CRONJÉ.

New challenges, new strategies in research applied to design and communication Juan ARRAUSI

Bringing practice to the theory: Project-led education in Industrial Design Engineering Winnie DANKERS, Hiske SCHUURMAN-HEMMER, Thonie VAN DEN BOOMGAARD and Eric LUTTERS..

Exploring Colour and Light as Dynamic Elements of Space Through the Activities of an International Workshop Nada EL-KHOURY, TiiU POLDMA

UFSC Design Course. A brazilian study Marília Matos GONÇALVES, Luiz Salomão Ribas GOMEZ.....

Transformation and consequences: Do change and divergence in the premises of Bachelor of Design educations in Norway today reveal a need of a General Plan for design educations? Målfrid Irene HAGEN

Knowledge generation in doctoral design education Martina Maria KEITSCH.

Classroom Architect: Integrating Design Thinking and Math Jain KIM, Swee Hong David KWEK, Colin MELTZER, and Pilar WONG

Rethinking pedagogy for iterative design process learning and teaching Jennifer LOY and Samuel CANNING

How Can We Make It Better? Translating An Innovative Medical Model Into Cutting Edge Design Curriculum Barbara MCFALL, Cindy BEACHAM' Kathryn BURTON, Ron DULANEY JR

Designing FunWritr: unpacking an affinity-based, professionalizing, graduate-level educational technology design experience

Justin OLMANSON, Chung-Kai HUANG, Rob SCORDINO and Jaejin LEE......

Programming Sketches: a bricolage approach to teaching computer programming in design education

Juhong PARK....

Reflections and prospects about the relationship between master thesis and design project in interior architectural education

Ann PETERMANS, Jan VANRIE, Kris PINT and Koenraad VAN CLEEMPOEL. 155

The "Nature" of Design Education: teaching design fundamentals in an outdoor classroom Andrea QUAM. 
Contextually Teaching Motion Design

Gretchen Caldwell RINNERT

A "filing system" for teaching research skills in interior architecture education Jan VANRIEand Kris PINT.

Design Education for Social Sustainability SU VERNON

Low-tech skills in high-tech solutions Era: the cognitive benefits of basic craft techniques in formal design education Gordana VRENCOSKA

Developing Design Thinking Expertise in Higher Education Andrew WITHELL, Neil HAIGH....

\section{Assessment}

Mind the Gap: an evaluation of joint development practice between FE and HE tutors within art and design Samantha BROADHEAD, Sue GARLAND

Constitutive and regulating modes of learning in creative design education Elena BARTOMEU MAGAÑA and Octavi ROFES BARON.....

Aligning assessment, feedback and action planning for international students Robert HARLAND

A Preliminary Study on Time Management in Undergraduate Industrial Design Students Li-Hwa LIN, Wenzhi CHEN.

Normal Creativity: What 1,038 t-shirts can tell you about design education Peter LLOYD and Derek JONES

Creativity in the subject Art and Crafts: the weak link between learning and assessment EVA LUTNAES

Art as a Way of Learning: An Aesthetic Environment Assessment Tool Patricia Anna PINCIOTTI and Emily VERBA.....

Evaluating Architecture students' perspective of learning in peer reviews. Charlie SMITH.

\section{Internationalisation of design education}

Design Education and non-EU students: shifts in teaching practice Karen BULL, Jane OSMOND.

Multiculturalism as an Approach to Prepare Egyptian Government School Students for Micro-

Scholarship Through Art Workshop Walaa KASSEM.

City reflections: design collaborations for cross-cultural learning Kelly M. MURDOCH-KITT, Denielle EMANS.

Design English collaboration and presentation: Developing international designers at a Japanese university Mark D. SHEEHAN, Jack RYAN, Yasuko TAKAYAMA, Ikuro MINE, and Satoshi KOSE.....

A New Way To Improve Design Students' Creativity - Based on Thinking Style Yang ZHANG. 


\section{Philosophy of design education}

Social Design

Ruth MATEUS-BERR, Nisrine BOUKHARI, Florian BURGER, Alessia FINCKENSTEIN, Tanja GESELL, Marta GOMEZ, Masha HUPALO, Emer KINSELLA, Dieter LANG, Elaine LIU, Teresa MORANDINI, Marie-Christin RISSINGER, Frida ROBLES, Elisabeth STEPHAN, Stephan TRIMMEL, and Julian VEROCAI

Ecological Literacy in Design Education: A Foundation for Sustainable Design Joanna BOEHNERT....

Visual Grammar: A Literature Review Karen BRAENNE.

An exploration of design thinking across educational domains Demelza CUSENS and Hugh BYRD.

Changing Attitudes Towards Art and Design: Activating Expectations and Design Change Pete Quinn DAVIS...

Branded: the sister arts of rhetoric and design Susanna Kelly ENGBERS.

Making scholarship: Describing the field of inquiry and the research approach Laila Belinda FAUSKE

Development and pathology of Graphic Design in Iran Berhrouz FOLADI

From Tutor-led to Student-led design education: the Global Studio Aysar GHASSAN and Erik BOHEMIA....

Design values, designing values and valuing designing: three scenarios for values in design education.

Gabriel HERNÁNDEZ.

Which Way is Up? Space and Place in Virtual Learning Environments for Design Derek JONES and Peter LLOYD.

From Bauhaus to DESIS: exploring solution-focused methodology for social design education Yanki C LEE and Denny K L HO.

Digital gardens with real toads in them: the place of heritage media in a digital art and design education lain MACDONALD..

A Multidisciplinary Approach to Design Education: Providing a framework for informed designers of the future Zaiba MIAN

\section{- Volume 2 -}

Teaching Constraints, Learning Creativity: Leveraging the Guided Distractions Margherita PILLAN, Marco MAIOCCHI and Marko RADETA......

Teaching Design Project in sight of Design Partnership: a new-old way to teach Design Flavia Nizia RIBEIRO, Roberta PORTAS, Maria Apparecida MAMEDE-NEVES, Izabel OLIVEIRA and Rita COUTO....

Enhancing structured reflective practice to complement the "Design Praxium" vision Fernando ROJAS.

Design for a city state: An overview of design education in Singapore Peer M. SATHIKH. 


\section{Design knowledge}

The Music without Melody of John Cage, the Literature without Words of James Joyce, the Art without a Subject of Joseph Beuys and the Architecture without Construction of Enric Miralles Irma ARRIBAS

The introduction of new technologies in design: a Brazilian perspective Denise Silva BATISTA, Priscilla STREIT and Sydney Fernandes FREITAS

Developing (architectural) design knowledge: A learner-researcher study Tanja GOLJA and Lynette SCHAVERIEN

Informal peer critique and the negotiation of habitus in a design studio Colin M. GRAY....

Agile Thinking in Motion Graphics Practice and its potential for Design Education Jonathan HAMILTON

Like or dislike: Aesthetic judgements on textile patterns Siri HOMLONG.

Colour and Light in Design - Levels of experiencing colour and light

UIf KLARÉN, Harald ARNKIL and Karin FRIDELL ANTER

Mindfulness: The holy grail of design education?

Christian MONTAROU.

'What do you think the campus is telling you?' Teaching-led research exploring campus design and perception. Nicole PORTER.

The Intervention of Criticism into Practice Barbara PREDAN

Redesign of traditional Chinese umbrella Lisha REN and Fengyu GAO.

Counter-Design: Alternative Design and Research Methods Joshua SINGER

Applying Design to Learning: Cognitive Science Supports Visual Language Principles in the Design of Effective Reading Materials LOU TETLAN

The four-second window: how the time constraint of working memory and other psychological principles determine the success of a graphic design Pino TROGU..

Rotational geometry as a teaching tool: applying the work of Giorgio Scarpa Pino TROGU...

What does it mean to be a "materially attuned" practitioner? Maiko TSUTSUMI

Listening design: a new methodology for design and innovation processes Rosanna VENEZIANO, Patrizia RANZO, Giulia SCALERA and Mara ROSSI......

Research informed design education - Design education informing research

Versioning: full-scale prototyping as a prototype for design education? Robert M. ARENS and Edmond P. SALIKLIS.

So what do Design students really think? Exploring perceptions of Learning Landscapes Louise BARBOUR, Lindy OSBORNE and Glenda CALDWELL

Interdisciplinary Connections between Health Care and Design - a Case Study in a

Psychogeriatric Ward in Norway

Arild BERG and Tore GULDEN. 
Methodological Foundations of Design Pedagogy: The Scholarship of Teaching and Learning in Design

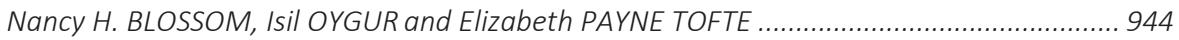

Examining the Textile Design Creative Practice Research-Teaching Nexus

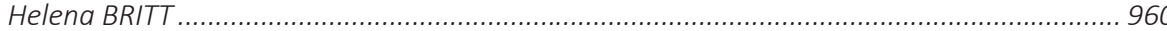

Undergraduate Design Studio Task to Internalize Learner Locus of Control

Charles COX and Géza FISCHL

From teaching sustainable product design to teaching sustainable behaviour design Johannes Zachrisson DAAE and Casper BOKS......

The role of identity development in design problem-based learning: essential challenges in sustainable design learning

David W. GARRETT and Tracy BHAMRA

Designing teaching - teaching designing: teacher's guidance in a virtual design studio Henna LAHTI and Pirita SEITAMAA-HAKKARAINEN

Design Knowledge from Practice(s) Helen MCALLISTER

Building appetites: the design of locative media apps for learning the networked city Andrew MORRISON and JOnnY ASPEN.....

The scholarship of teaching: threshold concepts and research informed design education Jane OSMOND.

Exploring Real-life Settings: Integrating Research and Learning as Thinking-and-Doing in Design Studio Projects TiiU POLDMA and Michael JOANNIDIS

A phenomenographic pilot study of students' conceptions of design research Jesvin PUay-Hwa YEO

Learning to See: Contribution to an Analysis of the Teaching of Free Hand Drawing by Kari Liv Brundin Torjussen at Oslo National College of Art and Design, 1947-1990 Grete REFSUM.

Designerly well-being: implications for pedagogy that develops design capability Kay STABLES

\section{- Volume 3 -}

A different approach on gaining practical experience by acting as an (open) innovator at Industrial Design Engineering Lenny VAN ONSELEN and Rianne C. VALKENBURG.....

Fostering deep learning in respect to the social aspects of sustainable product design Matthew WATKINS

\section{Multidisciplinary design education}

A case study on action research: Barri Gòtic Barcelona Xavi CAMINO and Albert FUSTER...

Multidisciplinary Design Education Rita Maria de Souza COUTO and Cristina PORTUGAL

Spatial and Service Design meet up at Coltivando Convivial Garden at the Politecnico di Milano Davide FASSI and Giulia SIMEONE.

Design as a second language. Design as a multicultural-multidisciplinary space of integration: Challenges and advantages of introducing design to non-design students, in a second language, in a new cultural context Carlos A. FIORENTINO, Andrea VAN DER REE and Lyubava FARTUSHENKO. 
Integrating multidisciplinary collaboration in undergraduate design education: Too many cooks spoil the broth?

Katja FLEISCHMANN.

Teaching the Design of Narrative Visualization: Using Metaphor for Financial Literacy and Decision Making Aaron FRY, Jennifer WILSON and Carol OVERBY...

Cross-cultural design attitude: open-ended design solution for welcoming the Diversity Elena Enrica GIUNTA and Agnese REBAGLIO

Wicked Futures: metadesign, resilience and transformative classrooms Les HOOPER, Sue Fraser WELCH and Natalie WRIGHT

An effect of multidisciplinary design education: creative problem solving in collaborative design process

Da Eun KWON and Sun Hee JANG.

Tell it with colours: Case study of Multidisciplinary educational program for non-designer Mari-Ann LETNES and Ingvild Olsen OLAUSSEN......

Mobile Museum Communication Design and new literacies Dagny STUEDAHL and Sarah LOWE.

Energy and Emotions: transdisciplinary design education for resource conservation Tatu MARTTILA, Karthikeya ACHARYA, LUtz GEGNER and Till BOVERMANN

Translations: Digital \& Physical Interchan1828 ges Kyle MILLER and Clark THENHAUS

Cultivating creativity: documenting the journey Grace SCHLITT.

Craft education: authentic design constraints, embodied thinking, and craft making Pirita SEITAMAA-HAKKARAINEN and Kaiju KANGAS....

Music iconography used as video montage guide - Conception, development and validation of a teaching module in Communication Design Jose SILVA

Multidisciplinary design for intercultural learning. Crafting digital services for a multicultural society Irina SUTEU and Margherita PILLAN.

A Polydisciplinary Journey: From Coffee to Prototype Carmen TRUDELL

\section{Challenges in design education methods}

Who is the Designer?: An Experience of Collectivism in Basic Design Course Humanur BAGLI and Koray GELMEZ....

Making, using and interpreting design probes: how subjective is participation? Cara BROADLEY and Marianne MCARA

Pedagogy for teaching design - with an emphasis on sustainable design Stephanie CARLEKLEV and Marie STERTE....

Another future for designers in America Kate CATTERALL....

Inspiring and Investigating Imaginative Capability of Design College Student Hsiang-Tang CHANG, Pei-Chin HSIEH and Tung-I LIN .

Learning problems and resources usage of undergraduate industrial design students in studio courses

Wenzhi CHEN and Hsien-Hui TANG. 1493 
Design: The continuous construction of competences Alexandra CRUCHINHO and Graça GUEDES..

Understanding the PhD by Publication David DURLING

Down the Rabbit Hole: a situated approach to design education that facilitates socially responsible emergent designers

Samantha EDWARDS-VANDENHOEK and Katrina SANDBACH.

Social Networking as a Mentoring and Engagement Tool Between Design Alumni and Early Design Students Lisa FONTAINE

Social Network as a Tool to Develop Personas for User Research: An Exercise from Design Education Koray GELMEZ and Humanur BAGLI

Materials Selection: from technical to emotional material properties Marta GONZÁLEZ and Javier PEÑA..

Adapting the Front-end of Innovation to its context: a methodological approach Alexis JACOBY

Students as choice-makers: developing altered consciousness as an aspect of design and global citizenship literacy

Steve KEIRL and Susan V. MCLAREN

Art and Design Schools in Transition: The Uncertain Future of the Workshop Model Martin Egge LUNDELL.

A methodology for appraisal and validation of User Centered Open Innovation Programs: a case study critical analysis of an energy supplier co-creative innovation program Américo MATEUS, Ana LOUREIRO, Carlos ALVES ROSA, SUSAna LEONOR.

"Learning by doing" revisited: an interactive experience in teaching design methods Ozge MERZALI CELIKOGLU and Sebnem TIMUR OGUT....

Simon Says Syndrome in Art and Design Education Muhizam MUSTAFA, Mumtaz Begum Aboo BACKER, A.S. Hardy SHAFII, Azila ZAINAL.

Relating creativity, fantasy, invention and imagination: studying collective models of creative collaboration from Kindergarten to University Degrees Raffaella PERRONE.

Educating multidisciplinary postgraduate product design students: challenges for a new programme

Stephen D. REAY and Andrew WITHELL.

\section{- Volume $4-$}

Design Puzzles as a learning platform for morphology design research Pedro REISSIG and Cristhian CASTRO ARENAS.

Teaching and evaluation strategies for drawing in design education: the use of drawing schemata as a tool for the in-class development of drawing for design Nora Karina AGUILAR and Jose LUis HERNANDEZ AZPEITIA

Design School: Design Education in the Age of Digital Capital Paul A. RODGERS and Craig BREMNER.

Design Schools as Incubators of Social Entrepreneurship Daniela SELLONI....

Systems Oriented Design: The emergence and development of a designerly approach to address complexity Birger SEVALDSON 
"Not two weeks in a place tidying-up the paper drawer" - an employability agenda case study Ian James SHARMAN and Zoe PATTERSON....

Liminal moments: designing, thinking and learning Manuela TABOADA and Gretchen COOMBS.....

Form, fit and flair: considering the design doctorate Laurene VAUGHAN and Andrew MORRISON

Design and business double education: cross-country comparison Fabiane WOLFF, Brigitte BORJA DE MOZOTA, Andrea CAPRA, Daniela SZABLUK and Julia Stephanou NASCIMENTO .

Teaching New Product Development to Design Led Innovation Cara WRIGLEY and SAM BUCOLO.

Constructing design knowledge built up on the kindergarten education Meryem YALCIN .

\section{Design education for non-designers}

Connecting for Impact: multidisciplinary approaches to innovation in Small to Medium sized Enterprises (SMEs) Mark BAILEY, Neil SMITH and Mersha AFTAB

I "Like" Design: Participatory Web Sites and Design Lessons for the Masses Mary Anne BEECHER.

Student Goes on a Journey; Stranger Rides Into to the Classroom: Narratives and the Instructor in the Design Studio

Elizabeth BOLING, Martin A. SIEGEL, Kennon M. SMITH and Patrick PARRISH

Designing a creativity training plan for companies Marita CANINA, Elisabetta COCCIONI, Laura ANSELMI and Stefania PALMIERI

HCID: Who is an interaction designer? Alma Leora CULÉN, Joshi Govind SUHAS and Atif ABDELHAKEEM

Technology and Design as part of a public school from $1^{\text {st }}$ to $10^{\text {th }}$ grade Liv Klakegg DAHLIN, Liv Oddrun VOLL and Anne-Gunn SVORKMO......

Learning from co-designing Hua DONG and Shu YUAN

Design Minds: An online design education platform for non-designers to enact cultural change Christian DUELL, Natalie WRIGHT and Joanna ROXBURGH.....

Hooked on peers' drawings: Learning through the visual wildfire Nina Scott FRISCH.

What is Industrial Design? Providing a Guide for University Applicants Michael GOATMANand Louise MOODY

Sketching design thinking: representations of design in education and practice Colin M. GRAY and Martin A. SIEGEL

Teaching 'design thinking' in the context of Innovation Management-from process to a dialogue about principles Monika HESTAD and Jamie BRASSETT .

Practically Creative: The Role of Design Thinking as an Improved Paradigm for $21^{\text {st }}$ Century Art Education

Delane INGALLS VANADA.....

The imaginative approach: Characteristics of craft artisans' and design trainers' in-depth cognitive levels during a design training program

Deny W. JUNAIDY and Yukari NAGAI 
Visualising ideas: a camera is not enough Liv Merete NIELSEN..

Digital design and creativity: A reflection on curriculum change in landscape architecture education

Heike RAHMANN and Jillian WALLISS

OutReach Initiative for Education of Future Industrial Designers

Claudia B. REBOLA and Kevin SHANKWILER.

Learning by watching: what we can learn from the Inuit's design learning Janne Beate REITAN.

Introducing high school students to design and creative thinking in a teaching lab environment Gretchen Caldwell RINNERT and Jillian COOREY.....

Rock Paper Scissors: Reflective Practices for design process in the landscape architecture novice

Jennifer SEEVINCK and Thomas LENIGAS.

Building the Narrative Cloud: Reflection and Distributed Cognition in a Design Studio

Classroom

Omar SOSA TZEC, Jordan E. BECK and Martin A. SIEGEL

Educating Process of Design to Learn Urban Park Design for Non-Landscape Architecture

Students

Rahman TAFAHOMI, Seyed Moslem Seyed ALHOSSEINI, Farshad NOORIAN Hasanuddin LAMIT and Haidar HABIBIE.....

K-12 Design Education, Creativity, and The Corporate World Robin VANDE ZANDE

Human-Centered Design in Primary Schools: a Method to Develop Empathy with and Knowledge of the Needs of Elderly

Fenne VAN DOORN and Remke KLAPWIJK

A methodological approach to modelling design led innovation across secondary education: An Australian case study Natalie WRIGHT, Cara WRIGLEY and SAm BUCOLO

The creative citizen: Understanding the value of design education programs in the knowledge economy

Natalie WRIGHT, Rebekah DAVIS and Sam BUCOLO.........

\section{E-learning}

From Long-distance to No Distance: Performance-based long-distance education in art and design Bo GAO.

Supporting Art and Design student transition into Higher Education Julie HASLAM and W. Rod CULLEN

Feel the Fear: Learning Graphic Design in Affective Places and Online Spaces Anitra NOTTINGHAM

Developing interactive learning environments to promote scaffolding and reflection: A look at the Digital Process Book for design studio education and comparisons to K12 science education applications

Lori BRUNNER STONE, Abigail LUNDQUIST and Stefan GANCHEV....

E-learning as a balanced way of teaching museums and exhibitions to provide both theoretical and practical education

Dina ZAKI 


\section{Introductions}




\section{Design Learning for Tomorrow - Design Education from Kindergarten to PhD}

Many thanks to the Design Research Society (DRS) and Cumulus for giving the Oslo and Akershus University College of Applied Sciences the confidence to chair and organise this $2^{\text {nd }}$ international conference for design education researchers in Oslo May 14-17, 2013. Researchers from more than 74 universities have undertaken a rigorous double blind review process used to select papers for inclusion in these conference proceedings. We received 225 full papers and of these 165 were selected and included in the conference proceedings and presented at the conference. Thanks to all, and a special thank to professor Peter Lloyd of the Open University, who served as chair of the scientific review committee and to dr. Janne Reitan of the Oslo and Akershus University College of Applied Sciences who chaired the committee with him.

The $2^{\text {nd }}$ international conference for design education researchers in Oslo May 1417, 2013 on the theme of 'Design learning for tomorrow - Design education from Kindergarten to $\mathrm{PhD}^{\prime}$ received an overwhelming response. This is gratifying for us, the organisers, as we see design in a broad interdisciplinary perspective in support for a better tomorrow. For years we have promoted the idea that sustainable design solutions should include more than 'professional' designers; they should also include a general public as 'conscious' consumers and decision makers with responsibility for quality and longevity, as opposed to a "throw-away" society.

This is also the reason why we as the conference hosts have chosen to focus on design education from Kindergarten to PhD. This perspective was put forward as a contrast to most design education conferences where there is either a focus on design education for professionals or general education for children and non-designers. In the call the conference papers we have argued for a longitudinal perspective on design education where the education of professional designers is seen in relation to general education of a people. This is becoming increasingly relevant as more and more decisions are being made on the basis of visual representation. With this conference we have the ambition to see education at many different levels in securing a sustainable future for the design of everyday life solutions. For that we need qualified and reflective decision makers with a consciousness for quality of design and solutions.

Why are these issues of concern for Norwegian researchers in this field? The answer goes back to the 1960 National Curriculum for primary and lower secondary schools in Norway, when art and crafts were merged into one subject. Currently this subject includes art, architecture, design and visual communication. No other Nordic-or European-country seems to have developed a model similar to this and today we see 
the benefit of this merger where design is at the core of the subject for youngsters building upon the best from art and the best from craft to become creative problem solvers and critical consumers. I am looking forward to the day when UNESCO, or other organisations with responsibility for funding research, recognise that we need more research and knowledge on what impact design education from Kindergarten to PhD have on consumer habits and sustainable development at large. I hope that such projects are not far away. Politicians have far too long been told that advanced mathematics is the main way to stimulate youngsters to abstract thinking. The designerly way of solving problems can be even more suitable in training abstract thinking, and it will also include ethical aspects of sustainable development and ecology. A design literate general public would therefore be a step forward in supporting the statement of commitment by the members of Cumulus; the 'Kyoto Design Declaration 2008'.

For this DRS//cumulus Oslo 2013 conference we are happy to continue our international cooperation for design education research. In advance of the conference we have cooperated on editing the conference proceedings at level 1 in the Norwegian system. After the conference we will cooperate for special issues of the following academic journals; Art, Design \& Communication in Higher Education, TechneA, Design and Technology Education, Studies in Material Thinking and FORMakademisk. The role of journals as an arena for design education research is essential for the advancement of knowledge production within the field. For the Nordic design and design education research field, FORMakademisk has played a crucial role in its five years of existence, as a digital open-access journal for both design and design education research. Its first editorial wrote that:

The aim of the journal is to provide a venue for research in design and design education, and thereby develop an interest and working community of scholars in the field. The editorial team perceives design as a generic term that includes creative and performing activities in the great span of the artefacts 'from the spoon to the city'. The editorial team relates to design education as a field that includes the dissemination of design in society and the teaching of design at all levels general education, vocational preparation, professional education and research education - from kindergarten to doctorate.(www.formakademisk.org)

The Norwegian design education community includes design education for professional designers and teacher training for design educators. The teacher training is mainly developed through two master programmes-one in Oslo (Institute of Art, Design and Drama, Faculty of Technology, Art and Design, Oslo and Akershus University College of Applied Sciences - HiOA) and one in Notodden (Department of Art Education, Telemark University College - HiT). Two PhD-programmes; Oslo School of Architecture and Design (AHO) and Cultural Studies at the Telemark University College, have a focus on both design and design education. The AHO programme was chaired by professor Halina Dunin-Woyseth, who has played a key role in developing research within the 'making disciplines'. From the AHO programme the research network DesignDialog was established in 2002 with research focus on three themes; 1) Studies of dialogues of design in context, 2) Studies of design education, and 3) Studies of public dialogues on design.

I see this conference as a further step to international collaboration in design education research. Thanks to all those at HiOA, Faculty of Technology, art and design, who have supported this conference; Dean Petter Øyan and institute leaders Åshild 
Vethal - Institute of Art, Design and Drama, Gunnar H. Gundersen - Institute of Product Design, and Laurence Habib - Institute of Computer Science. Without their support this conference would not have been possible. Thanks are also due to the leaders of Oslo and Akershus University College of Applied Sciences, rector Kari Toverud Jensen and head of research Frode Eika Sandnes, for general support to the internationalisation of design education research at HiOA, including this conference.

It is an honour for us that the DRS-Cumulus partnership will be signed in Oslo by DRS chair professor Seymour Roworth-Stokes and Cumulus vice-president professor Luisa Collina. Professor Michael Tovey and co-chair of this conference Erik Bohemia have played a central role in preparing for this partnership and this $2^{\text {nd }}$ conference for design education researchers.

Warm thanks to the Scientific review committee, the Scientific review panel, the Programme Committee, the Organising committee, and the rest of the Editorial team; Janne Beate Reitan, Peter Lloyd, Erik Bohemia, Ingvild Digranes and Eva Lutnæs. Thanks also to colleagues and students for valuable contributions.

We are also grateful to our supporters and sponsors; the National Museum, the Research Council of Norway, the musicians and designers Peter Opsvik and Svein Gusrud, the furniture companies SAVO, HÅG, STOKKE and Variér for generously providing display chairs for the exhibition, and all the other supporters and cooperation partners.

We hope, as the organizers, that the conference will promote design and design education as a field of practice and inquiry. We hope that it will create a fertile context for establishing new networks of future co-operation, nationally and internationally, and that design education research in its broad context will be recognized both inside and outside the design research community. The general public's interest for design and quality is developed from the kindergarten, through primary and secondary education and the public's attitude is central for professional activities and a broad democratic design participation.

Liv Merete NIELSEN

Professor, designer

Chair of the conference 


\section{Design Pedagogy Special Interest Group of DRS}

This is the second symposium organised jointly by the Design Research Society and CUMULUS. The two organizations complement each other. CUMULUS is the International Association of Universities and Colleges of Art, Design and Media. It is a non-profit organization consisting of 165 universities and colleges of art, design and media from 43 countries. Cumulus was founded in 1990 and since then has been acting as an umbrella for many purposes and numerous projects for education and research of art, design and media. The Design Research Society is a multi-disciplinary learned society for the design research community worldwide. The DRS was founded in 1966 and facilitates an international design research network in around 40 countries.

The Design Research Society has three main aims. It focuses on recognising design as a creative act, common to many disciplines. It has the intention of understanding research and its relationship with education and practice. Then there is the overall aim of advancing the theory and practice of design. The membership of DRS is international.

The Society's Special Interest Group in Design Pedagogy is one of five in the society. It aims to bring together design researchers, teachers and practitioners, and others responsible for the delivery of design education, and to clarify and develop the role of design research in providing the theoretical underpinning for design education. These aims are not directed simply at one type of design education, but are intended to include all ages. However as the current membership of DRS is predominantly from universities inevitably the conference stream has concentrated on design education at that level.

The first DRS/CUMULUS Symposium was held in Paris in 2011. Its overarching aim was to explore how innovation in education is informed by and is informing design research. The symposium focused on design education, innovation in general education through design, and on innovation in business and engineering education through design integration. There was a particular emphasis on developing research in the area of Design Pedagogy. It was successful and it marked the point at which the Design Pedagogy Special Interest Group became could be said to be established as an effective force in design research.

This was consolidated at the DRS Biennial Conference in July 2012 in Bangkok. Papers aligned with SIGs were streamed through the conference programme. The Design Pedagogy stream consisted of 24 papers which was a strong representation within the conference. They focused on teaching and assessment, education and learning, design methods and processes, design approaches, cognition and creativity, and design culture, with papers grouped accordingly. Attendance at the sessions was good with informed and lively discussion.

In recognition of the strength of the papers at the conference, 8 of them were selected to form the basis of a special issue of the Design and Technology Education Journal. It was edited by Erik Bohemia and Mike Tovey and it included a review of the conference and an editorial which related the developments in design pedagogy in 
higher education which the papers focused upon, to the wider issues of design teaching at the school level.

This second DRS/CUMULUS conference builds on these developments and develops them into new areas. Its theme of design learning for tomorrow encompassing design education from kindergarten to $\mathrm{PhD}$ is large and ambitious. The conference is intended to be an international springboard for sharing ideas and concepts about contemporary design education research. It is open to different facets of contemporary approaches to such research in any aspect and discipline of design education.

The context for this is set well by the organizers who say:

'Designed artefacts and solutions influence our lives and values, both from a personal and societal perspective. Designers, decision makers, investors and consumers hold different positions in the design process, but they all make choices that will influence our future visual and material culture. To promote sustainability and meet global challenges for the future, professional designers are dependent on critical consumers and a design literate general public. For this purpose design education is important for all. We propose that design education in general education represents both a foundation for professional design education and a vital requirement for developing the general public competence for informed decision making.'

This is a powerful and energising assertion for all of us involved in research in design pedagogy. It is possible that you could argue that this is what is needed, for despite a richness of activity, the number of journal papers on design pedagogy research could be higher. In a ranking of design research journals (Gemser et al, 2012) Design Studies was placed first. In the last year it has published only three papers on design pedagogy. This is better than the second placed journal, Design Issues, which has none, or another highly rated publication, The Design Journal which also has none. A challenge for scholars of research in design pedagogy is to achieve a greater impact amongst our journals.

Design research is not the same as research in some other disciplines. (Ref) In a fundamental science such as physics if research stops then effectively the discipline comes to a halt. If there is no physics research then there is no physics. Design is not like that. If design research were to stop then design would continue, more or less regardless. Designers would continue designing things, and probably the world would notice no difference. It would seem that design research is not central to design practice.

Design research is an activity which is directed to exploring and understanding the nature of design, its processes and methods. It has loftier academic aspirations than the data gathering part of the design process. It is usually undertaken by academics, and it is expected to conform to conventional standards of academic scholarship and rigour. Design research is clearly necessary for the academic respectability of the discipline.

One of the purposes of design education within schools is to equip students with the information and capabilities they need if they are to apply to study design at a university. It is an intention which probably applies to a minority of the students, but it is important nonetheless. In schools design education overall has to achieve much more and its broader reach is extremely important. It is important that research into design pedagogy should also have this wider relevance.

The recently published 'Design and Designing: a Critical Introduction' (editors S. Garner and C. Evans) is intended to provide an overview of design for those at school who are considering embarking on a university or college education in design. It 
consists of a collection of essays from a large number of contributors each concerned with a different aspect of design. In the first chapter for example Tovey asserts that the purpose of design education at this level is to provide students with a passport to enter the community of practice of professional design (Tovey 2012). For a significant time this has been the intention of practice based design education. Many students have the ambition of achieving a level of capability to function as designers in the professional world. In order to reach this standard they need to demonstrate a level of professional 'polish' and presentation to match that of the practising designer. However Tovey also argues that the most fundamental quality they need is one of creativity. The key to their achieving this lies in their abilities to think in a solution focused way employing visuo-spatial intellectual abilities. The ability to engage in creative thinking, and more particularly the creative synthesising of ideas through design thinking, is the most important capability required to enter the community of professional practice.

These are capabilities which need development from an early age. Abilities such as tackling problems with a solution focus, and thinking visuo-spatially are not developed ab intitio at university and college level. It has been argued that spatial ability is a fundamental form of intelligence along with others such a numerical and literary abilities.(Gardner, 1984) Cross has gone further in suggesting that designerly thinking might be a basic form of intelligence (Cross, 2006). Although the case for such a view is not proven, it is a productive stance to take as it helps to identify and clarify features of the nature of design ability and it offers a framework for understanding and developing it. What seems to be generally agreed is that these underlying capabilities are ones which need to be nurtured early and developed, not only as the basis for studying design but also to equip students with abilities needed across a range of occupations. As the organizers of this conference propose design education can make a vital contribution to the development of the general public competence for informed decision making. Thus design education can be seen to have a wide remit in both providing the next generation of designers, and developing competence in decision making more generally. If it is to meet these challenges then research into design pedagogy has a crucial role in supporting the development of innovative and effective design teaching.

Michael TOVEY

Convenor of the DSR Design Pedagogy Special Interest Group (PedSIG)

\section{References}

Cross, Nigel. 2006. Designerly Ways of Knowing. Springer: London.

Gardner, Howard. 1984. Frames of Mind: The Theory of Multiple Intelligences. New York: Basic Books.

Gemser, Gerda, Cees de Bont, Paul Hekkert, and Ken Friedman. 2012. "Quality perceptions of design journals: The design scholars' perspective." Design Studies no. $33(1): 4-23$.

Tovey, Michael. 2012. "The passport to practice." In Design and Designing, a Critical Introduction, edited by Steve Garner and Chris Evans, 5-19. London: Berg. 


\section{About the Design Research Society}

Design Research Society (DRS) is commending time, effort and energy and having already been investing these over the past 40 years to give rise to the most astute and relevant research in design.

When asked on numerous occasions to comment on design and design research, I've always been very careful, if not harsh, with regards to certain research projects whose content and/or approach seemed to fall short on the front of the relevant things in design. My reaction hit even closer to home in France where design is absent from academic disciplines, and design research has yet to really take off. I have to admit, nonetheless, that the strides undertaken by several universities abroad and continued by DRS have swayed me into believing that there really is an area that craves further learning and discovery, and cultivates fresh, relevance-hungry skills and competencies. Conferences and DRS-published works reflect a tremendous proliferation of new ideas, new projects and new ways to breed knowledge.

In 2010, and after having sat in on a conference in Seoul organized by the International Association of Societies of Design Research, I wrote the following: "Taking advantage of design's coming out and its lack of visibility research-wise for the purposes of Sociology, Psychology, Education Science, or even hard science, and playing them off as "design research" can only prove beneficial to design in the end. Employing the design research notion loosely, when, in reality, its usage is clearly career-geared, does not seem all that fitting to me either.

The scope of research needs to be clearly outlined in a category of its own, and based on a language that both captures and communicates the knowledge from all fields spanning social and hard science, not to mention the socio-economic challenges that riddle our everyday. Design is a language doubling as an interface that connects people, ideas and knowledge, and imagines them in a better tomorrow. We could come up with our own scientific version of it as long as we don't get carried away and throw everything together haphazardly merely because design is omnipresent, and it suffices to get the intellectual juices flowing every now and then."

Time may have elapsed since these thoughts first emerged, but the issue remains the same. This text reflected the questions that crossed my mind following the various presentations I had attended. One presentation, in particular, caught my attention. It was given by a doctoral student who claimed that the work he was doing on the design of a bicycle was research. Twenty years ago, designing a bike was considered design. Today, that same bicycle now aspires to fall under the category of "design research." Let's try and refrain from wanting to label any idea, even the most relevant, "research." Despite their efforts to make a hard science out of Marketing, business schools are 
busy filling in the gaps left behind by research done in the Marketing field. Every business owner and retailer in the world will tell you that Marketing is not a science, and wanting it to be one is just as futile as deciphering the gender of angels.

Design research is alive and well, and several universities have incorporated it into their agendas. It means nurturing a different kind of knowledge and insight at a time when other research fields lack the necessary to go head-to-head with the problems facing Mankind. There within is the incredible opportunity to truly, once and for all, set the fields of social and hard science apart. Kudos to DRS for being vigilant in choosing projects that are apt to map out a new direction between the two.

Just as design, creation and innovation are being positioned as solutions to problems in a world whose paradigms are crumbling, it would be, without a doubt, counterproductive for design research to cut ties with design practice. From an academic standpoint, it would also be a shame for design research to appear more virtuous and prestigious than design itself. That said, the loss would be just as great to reduce design to nothing other than a technique or representation. What design can offer goes beyond practicality. Design research goes beyond the designer. Their interconnectedness does not impede their individuality.

Design research and design itself are complementary. While loyal to the fundamental principles specific to each, both strive to find common ground and engage in a healthy give-and-take relationship to ensure balance and difference. With Mankind and its uses at the center of these issues, design gives impetus to an ideal or a potential, and not only pushes the limits of creativity and optimism to new heights, but seeks to defy them. At a time when science and technology are encountering a wary public, and where wealth and welfare are hitting glass ceilings, design provides an alternative future, and enables us to imagine it through a new lens. One thing is sure: Design researchers have their work cut out for them!

\section{Christian GUELLERIN}

President of Cumulus, International Association of Universities and Schools of Design, Art and Media 